\title{
PSTTTACUS LORY.
}

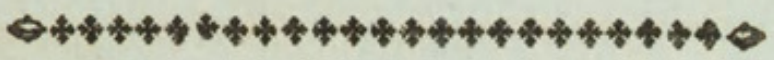

CHARACTER GENERICUS.

Rostrum aduncum: mandibula superiore mobili :

Nares in rostri basi.

Lingua carnosa, obtusa, integra.

Pedes scansorii.

$$
\text { Lin. Syst. Nat. p. } 139 .
$$

CHARACTER SPECIFICUS, Ëc.

PSITTACUS brachyurus coccineus, subtus cæeruleus, pileo nigro-violaceo, alis viridibus. PSITTACUS brachyurus purpureus, pileo violaceo, alis viridibus, pectore genibus caudaque cæruleis, orbitis incarnatis.

$$
\text { Lin. Syst. Nat. p. } 145 .
$$

In insulis Philippensibus generata pulcherrima hre avis indole est docili admodum et mansueta. Minor paululum turture, longa plerumque est circiter decem uncias. 


\section{whol owokThlet.

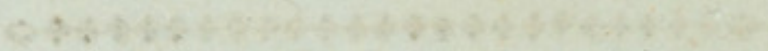

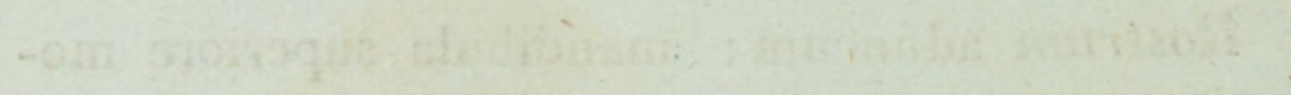

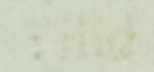

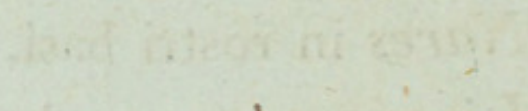

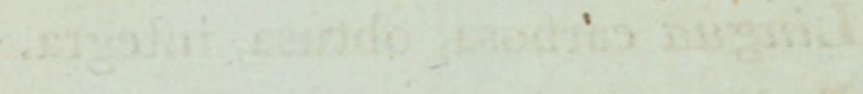

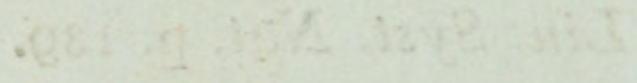

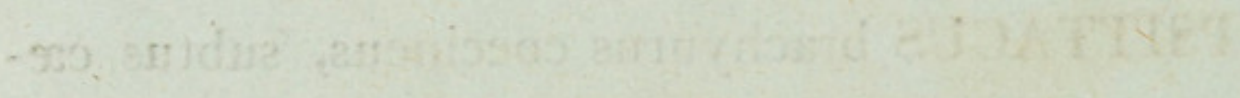

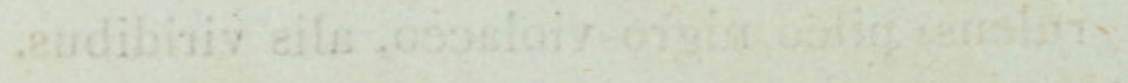

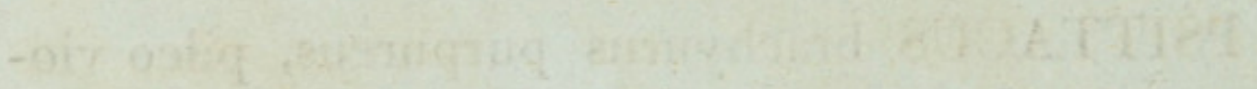

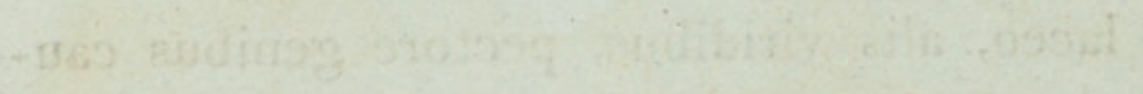

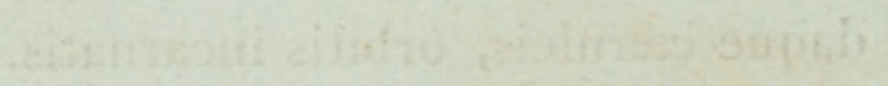

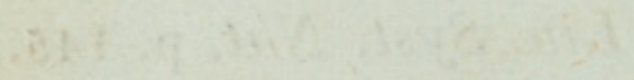

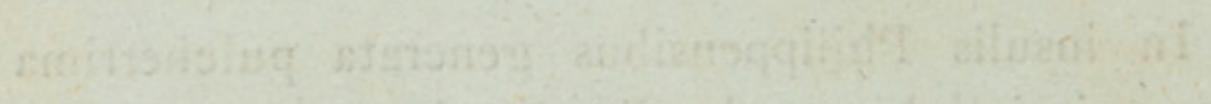

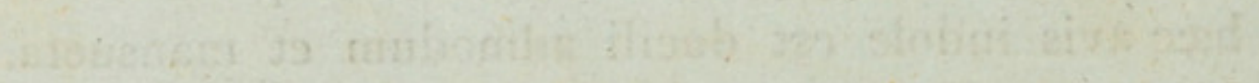

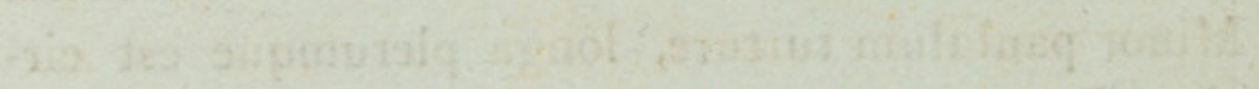
if 14 



\section{PHILIPPINE LORY.}

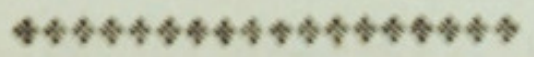

\section{GENERIC CHARACTER.}

Bill hooked : upper mandible moveable.

Nostrils round, placed in the base of the bill.

Tongue fleshy, broad, blunt at the end.

Feet scansorial.

SPECIFIC CHARACTER, EेC.

SHORT-TAILED SCARLET PARROT, blue beneath, with violet-black crown, and green wings.

BLACK-CAPPED LORY.

Edw.pl. 170.

LE LORI D'AMBOINE.

Pl. Enl. 518.

This most beautiful species is a native of the Philippine islands, and is remarkable for the gentleness of its manners in a state of captivity. It is somewhat smaller than a turtle-dove, usually measuring about ten inches in length. 


\section{$2 \mathrm{BHL}$ Biodiversity Heritage Library}

Shaw, George. 1804. "The Philippine Lory, Psittacus lory [PI. 633]." The Naturalist's Miscellany 15(CLXXX), https://doi.org/10.5962/p.311074.

View This Item Online: https://www.biodiversitylibrary.org/item/280634

DOI: https://doi.org/10.5962/p.311074

Permalink: https://www.biodiversitylibrary.org/partpdf/311074

\section{Holding Institution}

Museums Victoria

\section{Sponsored by}

Atlas of Living Australia

\section{Copyright \& Reuse}

Copyright Status: Public domain. The BHL considers that this work is no longer under copyright protection.

This document was created from content at the Biodiversity Heritage Library, the world's largest open access digital library for biodiversity literature and archives. Visit BHL at https://www.biodiversitylibrary.org. 